
secara kwantitas memang menunjukkan skala yang terus menanjak. Kendati demikian, hemat penulis, dari kwalitasnya masin jauh panggang dari apl, atau dengan kata lain kwalitasnya masih buruk. Salah satu indikator yang menunjukkan hal tersebut adalah minimnya bukubuku yang membahas tentang PAUD, lebih khusus lagi buku PAUD yang membeberkan tentang pengetahuan musik. Buktinya, saat penulis singgah di toko buku offline atau online dan perpustakaan, penulis tidak menjumpai buku PAUD yang khusus menulis tentang musik. Padahal pengetahun musik sangat dibutuhkan dalam proses pendidikan di sekolah PAUD. Andaikata narasi hitam itu terus berlanjut sudah tentu akan berdampak buruk bagi keberlangsungan penyelenggaraan kegiatan belajar mengajar di sekolah PAUD.

Berpijak pada kenyataan suram diatas, penulis lantas memutuskan untuk menulis buku ini. Dengan harapan, buku ini dapat mengisi langkanya buku PAUD yang khusus menguraikan tentang pengetahuan musik. yang khusus isi buku inl adalah ragam pengetahuan. tempat mereka bertugas. Ragam pengetahuan musik rangtermaklub padabukt int dan dibutukkanoleh gunt yang guri musik das , potret musik anak Indonesia, teknik teorer bernyeny, potret dak bermain gitar, teknik dasar bernyanyl, leknik dasar bermain gitar, teknik metode penciptaan lagu anak, dan pengelolaan
Pada proses penyelenggaraan sekolah PAUD, musik yang dibutuhkan guru-guru PAUD ketika melaksanakan program pendidikan di sekolah PAUD

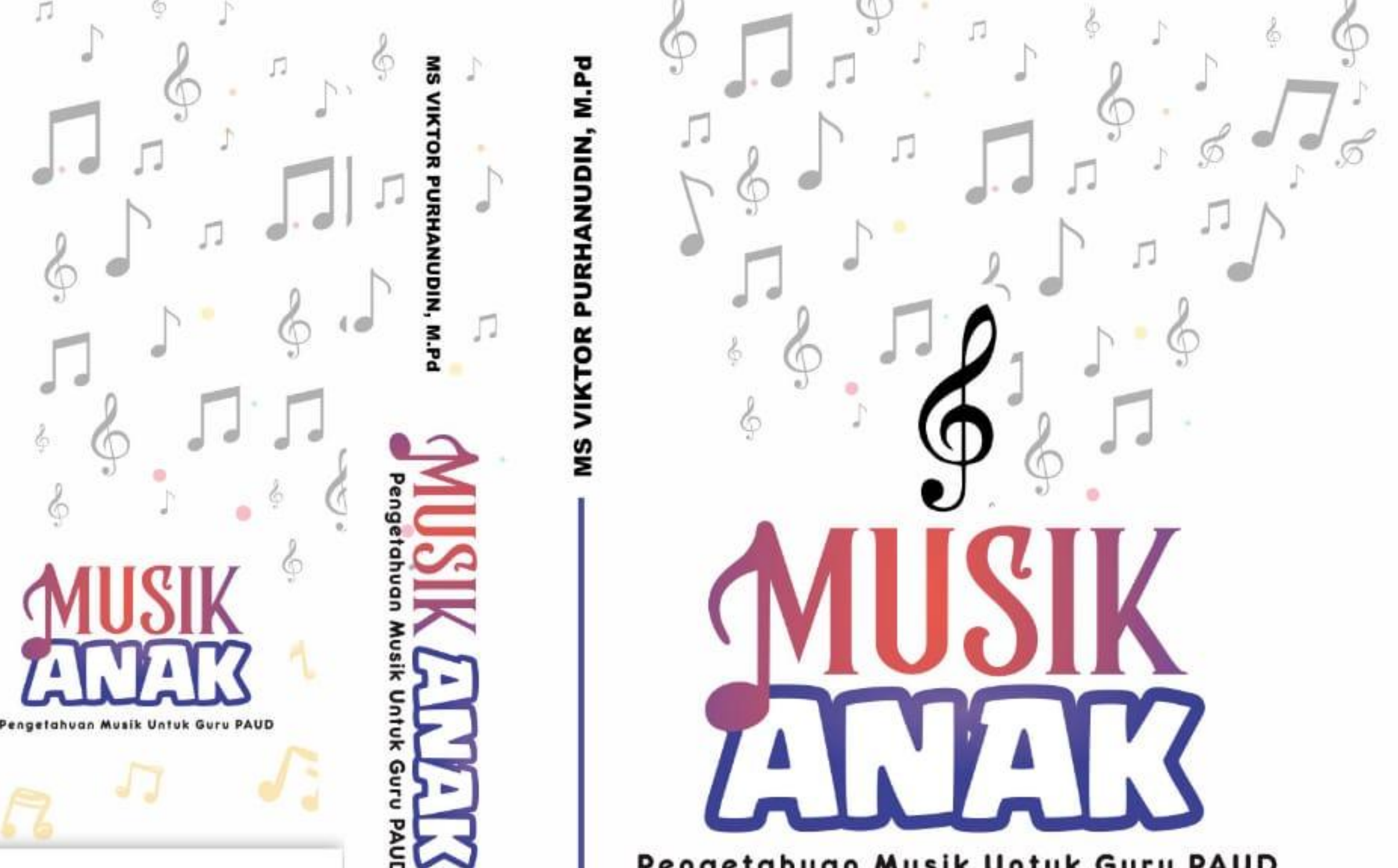

MS Viktor Purhanudin, M.Pd, lahir 2 Maret 1986, di Kendal, Jawa Tengah. Dia adalah dosen bidang Pendidikan Seni S 1 Program Studi Pendidikan Islam Anak Usia Dini Institut Agama Islam Negeri Salatiga. Selain itu, saat ini, dia juga tercatat sebagai Salatiga. Selain mahasiswa Dokn, Progra Neri Pendidikan Seni Musik Anak : Pengetahuan Musik Untuk Guru PAUD', merupakan salah



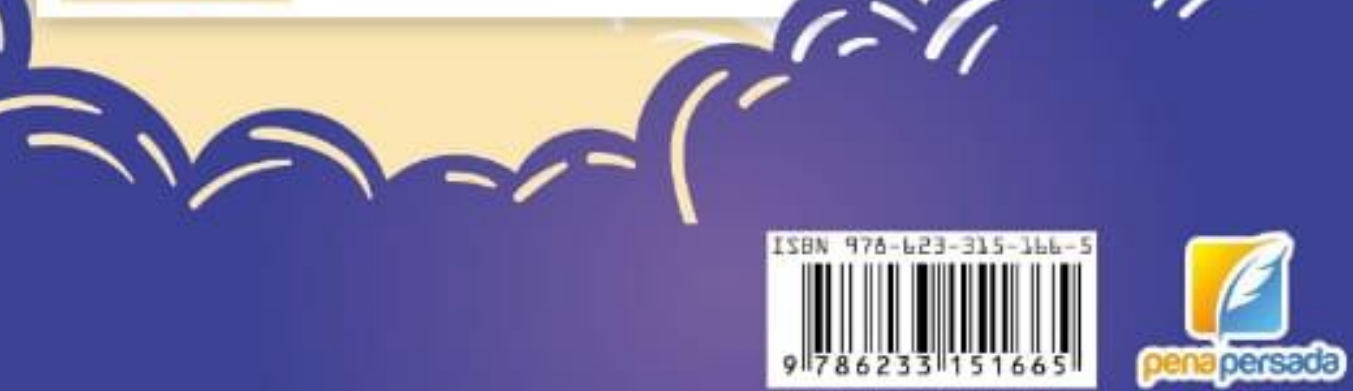

\section{Pengetahuan Musik Untuk Guru PAUD}




\section{MUSIK ANAK \\ PENGETAHUAN MUSIK UNTUK GURU \\ PAUD}

MS VIKTOR PURHANUDIN, M.Pd



PENERBIT CV. PENA PERSADA 


\title{
MUSIK ANAK \\ Pengetahuan Musik Untuk Guru PAUD
}

\author{
Penulis: \\ MS Viktor Purhanudin, M.Pd
}

ISBN : 978-623-315-166-5

Editor : Hesti Ariestina

Design Cover :

Retnani Nur Briliant

Layout :

Eka Safitry

Penerbit CV. Pena Persada

Redaksi :

Jl. Gerilya No. 292 Purwokerto Selatan, Kab. Banyumas

Jawa Tengah

Email : penerbit.penapersada@gmail.com

Website : penapersada.com Phone : (0281) 7771388

Anggota IKAPI

All right reserved

Cetakan pertama : 2021

Hak Cipta dilindungi oleh undang-undang. Dilarang memperbanyak karya tulis ini dalam bentuk apapun tanpa izin penerbit 


\section{Pessembaban}

Buku ini penulis persembahkan untuk adik-adik mahasiswa S 1 Program Studi Pendidikan Islam Anak Usia Dini (PIAUD) FTIK IAIN Salatiga dan segenap guru PAUD di Indonesia.

\section{Motto}

Tidak ada hal yang mustahil selama kita yakin dan berusaha. Yakin dan berusaha ialah jembatan emas menuju tersampainya apa yang kita cita-citakan. Yakin, usaha, dan sampai menjadi tiga kata ajaib yang sanggup mengantarkan kita dalam pusara kesuksesan. 


\section{PRAKATA}

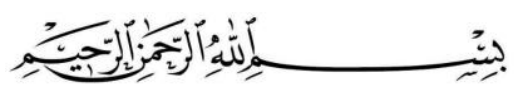

Atas terselesaikanya penulisan buku "Musik Anak:Pengetahuan Musik Untuk Guru PAUD", penulis mengucapkan syukur yang tidak terhingga kepada Tuhan semesta alam. KarenaNya buku ini dapat rampung dan dapat hadir dihadapan para khalayak pembaca, khususnya guru-guru PAUD dan mahasiswa PAUD diselurah Nusantara.

Penulis sangat berharap buku sederhana ini dapat memberi kontribusi positif bagi kemajuan dunia PAUD Indonesia. Terlepas dari harapan itu, penulis sangat menyadari bahwa penulisan buku ini tentu masih banyak terdapat kekurangan dan kesalahan. Pasalnya, kesempurnaan hanya milik Tuhan semesta alam. Oleh karena itu, saran dan kritik dari para pembaca buku ini sangat penulis harapkan, agar kedepan buku kecil ini dapat penulis revisi dan perbarui supaya mendekati kesempurnaan.

Pada proses penulisan buku ini, penulis banyak mendapat motivasi dari orang-orang yang punya andil besar dalam kehidupan penulis. Orang-orang tersebut meliputi kedua orang tua, Normalia (istri penulis), Juara (putra penulis), Agatha (saudara penulis), Bapak Mufig, Dr. Rasimin, Dr. Sunarto, dan sejumlah kolega penulis di organisasi Perkumpulan Profesi Musik Indonesia (Perpromi) yang tidak bisa penulis sebutkan satu-satu. Karena itu, sudah sepatutnya penulis mengucapkan seribu kata terima kasih untuk orang-orang tersebut. 
Selain itu, tidak lupa penulis mengucapkan terima kasih yang sebesar-besarnya kepada IAIN Salatiga. Tanpa institusi pendidikan tersebut, sudah pasti penulis tidak akan sanggup menyelesaikan buku ini. Bagi penulis IAIN Salatiga adalah mesin penggerak utama untuk terus berkarya dan melahirkan tulisan-tulisan selanjutnya. Akhir kata penulis ucapkan selamat membaca buku "Musik Anak: Pengetahuan Musik Untuk Guru PAUD".

Kendal, 6 Febuari 2021

MS Viktor Purhanudin, M.Pd 


\section{KATA PENGANTAR}

\section{Dr. Sigit Purnama, M.Pd \\ Ketua Umum}

Organisasi Perkumpulan Program Studi PAUD Indonesia

Musik tak bisa lepas dari anak-anak. Sejak di kandungan, seorang anak sudah dikenalkan musik oleh orangtuanya, bahkan setelah lahir segala mainannya pun bernuansa musik. Jadi musik sudah mengalir di darah setiap anak. Hal tersebut dikarenakan musik mempunyai berbagai manfaat untuk anak-anak. manfaat musik untuk anak-anak adalah dapat menunjang pertumbuhan fisik dan otak anak, membantu mengajarkan anak hal-hal baru, meningkatkan kerja otak, daya ingat, dan kemampuan berpikir, meningkatkan kemampuan membaca, menulis dan berhitung, meningkatkan konsentrasi serta meningkatkan kepercayaan diri.

Banyaknya manfaat musik untuk anak-anak ini yang mendorong seni musik di masukkan dalam kurikulum pendidikan. Pada satuan pendidikan anak usia dini musik sudah mulai dikenalkan. Pada satuan pendidikan tersebut musik mendominasi dalam pembelajarannya. Untuk itu Guru yang mengajar pada satuan pendidikan anak usia dini harus menguasai tentang musik anak. Pengetahuan tentang musik anak tidak hanya bisa didapat dari bangku kuliah saja, tetapi bisa didapat dari buku referensi tentang musik anak. 
Buku referensi pengetahuan dasar tentang musik sangat dibutuhkan oleh guru pendidikan anak usia dini untuk menunjang proses belajar mengajarnya. Namun pada kenyataannya buku referensi tentang musik anak tersebut susah didapat sehingga guru mengajar hanya sekedar mengajar sepengetahuannya saja dan minim teori. hal tersebut yang menyebabkan minat bakat musik anak kurang maksimal.

Kegelisahan guru-guru PAUD terjawab dengan adanya buku Musik Anak : Pengetahuan Dasar untuk Guru PAUD karya MS Viktor Purhanudin, M.Pd. Buku yang berisi tentang pengetahuan musik itu meliputi apresiasi musik, teori musik dasar, musik anak Indonesia, teknik dasar bernyanyi, teknik dasar bermain gitar, teknik dasar bermain drum, bermain pianika, metode penciptaan lagu anak, dan managemen pertunjukkan musik di PAUD. Buku ini bagai hujan di musim kemarau. Kekeringan pengetahuan dasar tentang musik anak ini di guyur oleh buku karya MS. Viktor Purhanudin, M.Pd tersebut. Buku ini dapat dijadikan pedoman para guru PAUD untuk mengajar musik dan juga menggali keterampilan bermusik peserta didiknya.

Bagi guru-guru PAUD, guru sekolah dasar maupun mahasiswa kependidikan buku ini sangat cocok digunakan untuk referensi dalam mendalami pengetahuan dasar tentang bermusik. Melalui buku ini juga kita bisa menggali keterampilan bermusik peserta didik.

Yogyakarta, 7 Februari 2021 


\section{PENDAHULUAN}

Tatkala buku ini penulis kerjakan, Pendidikan Anak Usia Dini (PAUD) sedang tumbuh subur dalam panggung pendidikan formal Indonesia. Hampir disetiap desa, kota, kabupaten, dan provinsi yang ada di nusantara berdikiri kokoh bangunan sekolah PAUD. Gambaran tersebut tentu menjadi khabar baik bagi masyarakat Indonesia, karena generasi bangsa khususnya anak usia dini dapat mengeyam pendidikan yang bagus. Oleh karena itu, merebaknya sekolak PAUD di Indonesia patut kita beri apresiasi.

Pada proses penyelenggaraan sekolah PAUD, secara kwantitas memang menunjukkan skala yang terus menanjak. Kendati demikian, hemat penulis, dari kwalitasnya masih jauh panggang dari api, atau dengan kata lain kwalitasnya masih buruk. Salah satu indikator yang menunjukkan hal tersebut adalah minimnya buku-buku yang membahas tentang PAUD, lebih khusus lagi buku PAUD yang membeberkan tentang pengetahuan musik. Buktinya, saat penulis singgah di toko buku offline atau online dan perpustakaan, penulis tidak menjumpai buku PAUD yang khusus menulis tentang musik. Padahal pengetahun musik sangat dibutuhkan dalam proses pendidikan di sekolah PAUD. Andaikata narasi hitam itu terus berlanjut sudah tentu akan berdampak buruk bagi keberlangsungan penyelenggaraan kegiatan belajar mengajar di sekolah PAUD.

Berpijak pada kenyataan suram diatas, penulis lantas memutuskan untuk menulis buku ini. Dengan harapan, buku ini dapat mengisi langkanya buku PAUD yang khusus menguraikan tentang pengetahuan musik. Sedangkan isi buku ini adalah ragam pengetahuan musik yang dibutuhkan guru-guru PAUD ketika melaksanakan program pendidikan di sekolah PAUD tempat mereka bertugas. Ragam pengetahuan musik yang termaktub pada buku ini dan 
dibutuhkan oleh guru-guru PAUD untuk mengajar itu meliputi apresiasi musik, teori musik dasar, potret musik anak Indonesia, teknik dasar bernyanyi, teknik dasar bermain gitar, teknik dasar bermain drum, bermain alat musik pianika, metode penciptaan lagu anak, dan pengelolaan pertunjukan musik di PAUD.

Dalam buku ini, masing-masing pengetahuan musik tersebut penulis jabarkan secara ringan, agar mudah dipahami oleh pembaca. Selain itu, penjabaran materinya juga masih bersifat pengenalan atau pengantar. Oleh karena itu substansi isinya tidak terlalu mendalam. Hal itu memang sengaja penulis lakukan, sebab, pembaca buku ini adalah khalayak guru PAUD, yang hemat penulis pengetahuan musik mereka mayoritas belum begitu mahir. Tesis ini menjadi lumrah lantaran di kampus jurusan PAUD sebagai tempat mencetak guru PAUD rata-rata hanya memberi kuliah musik sangat sedikit.

Bacalah buku ini dari bab 1, lanjut bab 2, lanjut bab 3, dan seterusnya. Melalui cara itulah pembaca akan mudah memahami keseluruhan buku ini. Karena buku ini terdiri dari dua aspek, yakni teoritis dan praktik. Oleh karena itu, untuk dapat memahami dan menguasai isi buku ini khususnya yang bagian praktik, pembaca mesti ikut mempraktikan ajuran-anjuran yang tertera dalam buku ini. Akhirnya penulis ucapkan selamat membaca dan mempraktikan apa yang tertuang dalam buku ini. Percayalah! Dengan proses itu pembaca akan lebih memahami musik sebagai bekal melakukan kegiatan pendidikan musik di PAUD. 


\section{DAFTAR ISI}

HALAMAN JUDUL.............................................................

HALAMAN PERSEMBAHAN..........................................ii

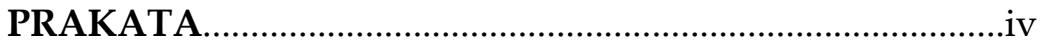

KATA PENGANTAR ...........................................................

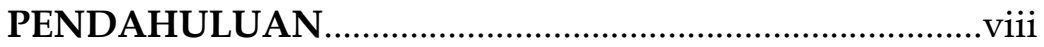

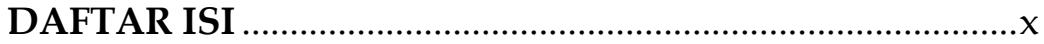

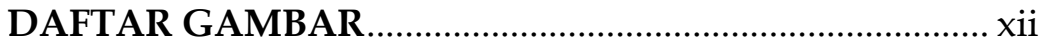



Bab 1 Apresiasi Musik..........................................................1

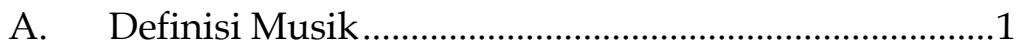

B. Sejarah Singkat Musik...................................................

C. Elemen-Elemen Penciptaan Musik ..............................10

D. Fungsi Musik Dalam Kehidupan Manusia.................13





B. Akor Dan Kadens .....................................................17

C. Ilmu Bentuk Lagu .............................................................

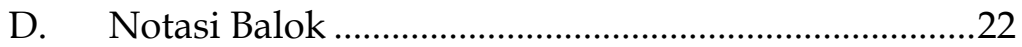

Bab 3 Musik Anak Indonesia .............................................28

A. Sejarah Musik Anak Indonesia ....................................28

B. Biografi Tokoh Musik Anak Indonesia ......................31

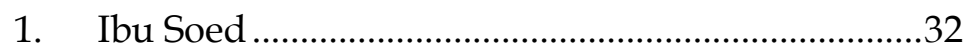

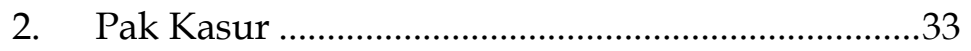

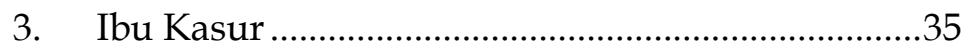

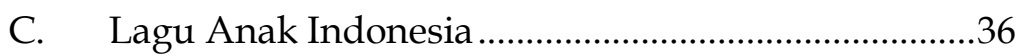

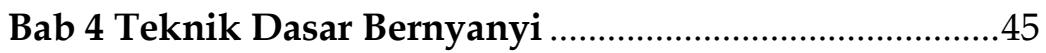

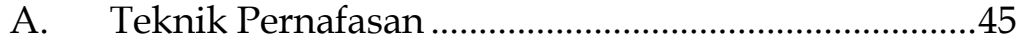



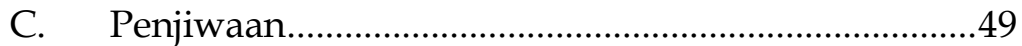

D. Penggunaan Pengeras Suara ........................................51

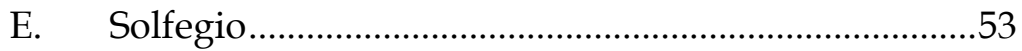


Bab 5 Teknik Dasar Bermain Gitar.......................................59

A. Sejarah Gitar Di Indonesia ..........................................59

B. Jenis Gitar Dan Anatominya .......................................61

C. Langkah-Langkah Bermain Gitar Akustik ................64

Bab 6 Teknik Dasar Bermain Drum.......................................70

A. Drum Dan Alat Pemukul Drum...................................71

B. Posisi Bermain Drum ...................................................73

C. Pukulan Dalam Permainan Drum .............................74

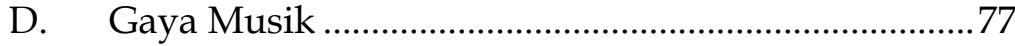



A. Pengenalan Alat Musik Pianika ................................ 82

B. Posisi Bermain Alat Musik Pianika..............................84

C. Lagu Untuk Berlatih Pianika ...................................... 85

Bab 8 Metode Penciptaan Lagu Anak................................104

A. Ciri-Ciri Lagu Anak .................................................105

B. Langkah Menciptakan Lagu Anak ...........................106

Bab 9 Managemen Pertunjukan Musik Di PAUD .............110

A. Menyiapkan Penyaji...................................................111

B. Menyusun Kepanitian ............................................... 112






\section{DAFTAR GAMBAR}

Gambar 1 Gobustan, salah satu alat musik zaman prasejarah.

Gambar 2 Artefak karya musik zaman kuno 'Seikilos', ditulis dalam notasi Yunani kuno

Gambar 3 Tangga nada diatonik mayor dan minor natural ditulis dalam notasi balok.

Gambar 4 Akor-akor dalam tangga nada diatonik mayor dan minor, ditulis dalam notasi balok 18

Gambar 5 Al-Farabi, penemu notasi balok 23

Gambar 6 Macam lambang birama dalam notasi balok ......25

Gambar 7 Paranada merupakan kertas kerja penulisan musik notasi balok. .26

Gambar 8 Tanda kunci G dan F ditulis dalam paranada......27

Gambar 9 Ibu Soed .32

Gambar 10 Pak Kasur sedang mengajar musik......................34

Gambar 11 Ibu Kasur . .35

Gambar 12 Pengucapan huruf vocal yang baik .48

Gambar 13 Bentuk mulut pengucapan huruf-huruf vocal yang benar

Gambar 14 Pengeras suara, alat bermusik penyanyi atau vokalis .52

Gambar 15 . Suasana kampung Toegoe, tempat orang Indonesia mengenal gitar .61

Gambar 16 Bentuk Gitar Akustik serta anatominya

Gambar 17 Bentuk gitar elektrik dan penjelasan anatominya. .63 
Gambar 18 Posisi tangan kiri yang benar ketika memainkan

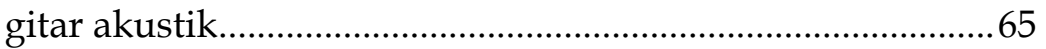

Gambar 19 Cara duduk yang benar saat bermain gitar

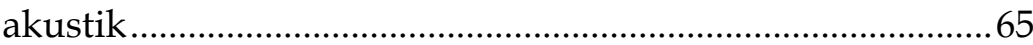

Gambar 20 Contoh petikan tirando ..........................................69

Gambar 21 Bentuk akor pada alat musik gitar akustik.........69

Gambar 22 Alat musik drum serta keterangnnya ..................71

Gambar 23 Pemukul drum dari kayu......................................72

Gambar 24 Pemukul drum yang berujung plastic .................72

Gambar 25 Pemukul drum hoats roads .................................73

Gambar 26 Pemukul drum brush ...........................................73

Gambar 27 Posisi duduk yang benar dalam bermain drum 74 Gambar 28 Seorang anak sedang bermain alat musik pianika 83

Gambar 29 Alat musik pianica 83 


\section{DAFTAR TABEL}

Tabel 1 Macam lambang tempo dalam notasi balok beserta keterangannya.....................................................................24 Tabel 2 Macam simbol dinamika dalam notasi balok serta penjelasannya ............................................................................24 Tabel 3 Macam simbol nada dan diam dalam notasi balok






\section{Bab 1 \\ Apresiasi Musik}

Dibab ini penulis hendak menjabarkan beberapa pengetahuan musik. Pengetahuan musik yang hendak penulis jabarkan dibab ini antara lain definisi musik, genealogi singkat musik, unsur-unsur penciptaan musik, dan fungsi musik dalam kehidupan manusia. Oleh sebab itu, pertanyaan yang patut penulis lempar dalam bab ini adalah: 1) Apa definisi musik? 2) Bagaimana sejarah singkat musik? 3) Apa saja unsurunsur penciptaan karya musik? 4) Apa fungsi musik dalam kehidupan manusia? Bab ini akan menjawab keempat pertanyaan itu.

\section{A. Definisi Musik}

Kita tahu bahwa musik menjadi satu bagian utuh dalam kehidupan manusia. Kenyataan tersebut dapat dijumpai dalam keseharian kita. Contohnya, saat kita santai, belajar, bekerja, bepergian, atau menggelar acaraacara hajatan, kerap kali kita ditemani oleh musik. Lantas, apa sebenarnya yang dimaksud dengan musik?

Definisi musik sangat banyak. Banoe (1985, p. 288) mengatakan "musik adalah cabang seni yang membahas dan menetapkan berbagai suara ke dalam pola-pola yang dapat dimengerti dan dipahami manusia". Perkembangan selanjutnya, Irnanningrat (2017, p. 2) mendefinisikan musik dengan rekayasa atau ciptaan manusia yang didapat dari hasil pemikirannya, yang kemudian dituangkan dalam suara-suara berbentuk lagu atau komposisi musik terdiri dari irama melodi

dan struktur-struktur penciptaan musik. Ditahun 
berikutnya, Oktarian (2020, p. 188) memberi definisi musik dengan produk kontemplasi manusia dan letupan ekspresi manusia yang ditorehkan melalui suara, yang didalamnya terkadung unsur-unsur penciptaan musik seperti melodi, nada, ritme, dan lainlain.

Musik, boleh jadi menjadi salah satu ciptaan manusia yang rumit, oleh karena itu definisinya sangat beragam dan tidak menetap. Kendati demikian, sebetulnya kita juga bisa menarik sebuah defenisi musik versi kita sendiri. Amati dan analisislah partitur musik yang terlukis pada halaman 2 !

10. BAGIMU NEGERI
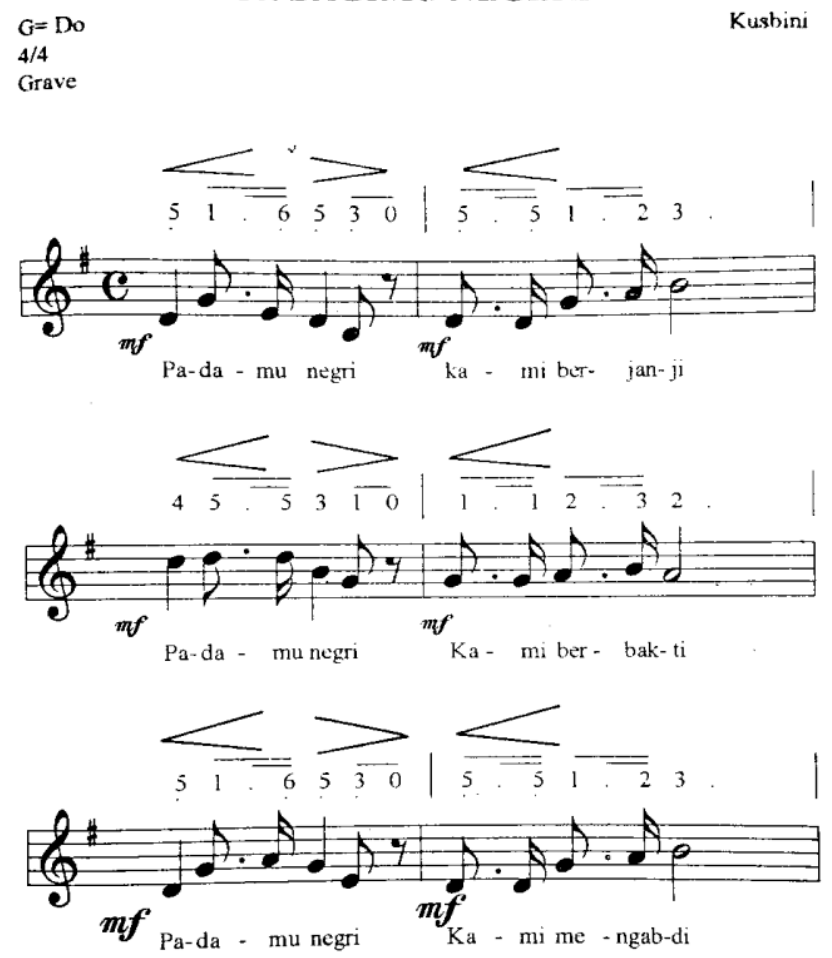

Potongan partitur lagu 'Bagimu Negeri'

(Sumber: Buku "Cintaku Negeri,

karangan DS. Soewito, hal. 29) 
Kalau kita mengamati dan menganalis partitur musik yang termaktup diatas, kita tentu akan menemukan sejumlah hal. Secara umum, sejumlah hal yang akan kita temui itu antara lain: judul karya musik, pencipta lagu, tonalitas, tempo, birama, nada-nada, melodi, ritme, syair, dan dinamika. Berpijak pada temuan-temuan tersebut, kita dapat menarik konklusi bahwa musik adalah karya cipta manusia yang berupa elemen-elemen penciptaan musik, dan karya ciptanya mesti tunduk terhadap dalil-dalil ilmu pengetahuan musik.

\section{B. Sejarah Singkat Musik}

Sjamsuddin (dalam Marli, 2012, p. 1) menulis, kata sejarah itu merupakan terjemahan dari kata 'history', suatu kata yang berangkat dari perbendaharaan kamus bahasa Inggris, sementara kata 'history' sendiri lahir dari kata 'historia', suatu kata yang terdapat dalam bahasa Yunani, dan makna kata historia adalah penelitian. Dari penjelasan Sjamsuddin tersebut, jadi sejarah dapat diartikan dengan penelitian.

Kalau kita menggunakan makna sejarah seperti kesimpulan penulis diatas tentu akan berbenturan dengan pehamaham sejarah pada umumnya. Sebab, pada umumnya orang memaknai sejarah dengan rangkaian peristiwa masa lalu yang penting, yang disusun secara cermat sehingga menghasilkan pengetahuan tentang masa lampau. Uraian tersebut dikuatkan oleh Robinson (dalam Marli, 2012, p. 2), menurutnya sejarah adalah segala hal yang diketahui manusia, dari yang lampau hingga yang terkini, dan hal-hal itu merupakan cetak biru peristiwa yang dianggap penting, dari proses itu muncul pengetahuan tentang masa lalu. 
Diatas dijelaskan arti kata sejarah. Lantas, pertanyaannya, bagaimana dengan sejarah musik? Rasanya susah untuk memberi jawaban pertanyaan tersebut dengan tajam dan akurat, karena sejarah musik tentu sangatlah luas serta komprehensif. Oleh sebab itu, disini, penulis hanya akan memberikan jawaban dari pertanyaan yang dimaksud secara ringkas saja. Bagaimana ringkasan sejarah musik?

Muttaqin (2008, p. 27) mengungkapkan sejarah musik lazimnya dapat diidentifikasi menjadi beberapa fase zaman, yakni: 1) Era kuno (Sebelum 600). 2) Era abad pertengahan (600-1450). 3) Era renaissans (14501600). 4) Era Barok (1600-1750). 5) Era klasik (1750-1820). 6) Era romantik (1820-1900). 7) Era kontemporer (1900Sekarang). Menurut penulis, uraian fase-fase sejarah musik yang diungkap oleh Muttaqin tersebut ada kekurangan, kekurangannya terletak pada fase yang paling awal, alasannya sebelum era kuno berlangsung masih ada era lagi yaitu era pra-sejarah. Terkait hal itu, maka ringkasan sejarah musik yang akan penulis uraikan disini dimulai dari era pra sejarah, kemudian dilanjutkan dengan era-era berikutnya.

Deskripsi sejarah musik ditiap-tiap zaman yang penulis terangkan barusan adalah sebagai berikut:

1. Musik era pra-sejarah. Tidak ada satupun orang yang hidup di zaman ini, yang dapat mengetahui dengan pasti bagaimana gambaran sejarah musik zaman prasejarah. Ihwal itu terjadi lantaran karya-karya musik zaman pra-sejarah telah lenyap, tidak ada satupun jejak karya musik zaman pra -sejarah yang ditemukan oleh para arkeolog. Namun begitu, satu pintu untuk mengungkap genealogi musik zaman pra-sejarah terbuka tatkala para arkeolog berhasil 
menemukan sejumlah alat-alat musik zaman prasejarah, salah satu nya gobustan, ditemukan kali pertama oleh para arkeolog di kota Baku, Azerbaijan (Setyorini, 2015). Dengan ditemukannya alat musik itu setidaknya membuktikan bahwa manusia zaman pra-sejarah telah hidup berdampingan dengan musik.



Gambar 1 Gobustan, salah satu alat musik zaman pra-sejarah (Sumber:

https://www.merdeka.com/gaya/ini-alat-musik-tertuadi-dunia-yang-dimainkan-sejak-zaman-

prasejarah.html)

2. Musik era kuno. Setelah zaman pra-sejarah runtuh, dunia dihuni peradaban baru yang acap disebutsebut dengan istilah zaman kuno. Di zaman kuno, musik mengalami lompatan kemajuan yang cukup signifikan. Itu ditandai dengan muncul beragam jenis alat musik baik yang berjenis idiophone, membranophone, chordophone, dan aerophone, fakta-fakta yang membuktikan kemunculannya yakni banyak ditemukan artefak-artefak peninggalan era kuno yang melukiskan bentuk jenis alat-alat musik yang penulis sebutkan tadi (Muttaqin, 2008, p. 27). 